\title{
Textile cosmetic pads based on psyllium and protein colloid in combination with the horsetail extract
}

\author{
DOI: $10.35530 / I T .070 .01 .1479$
}

OLIVERA ŠAUPERL

LIDIJA FRAS ZEMLJIČ

JULIJA VOLMAJER VALH

JASNA TOMPA

\section{REZUMAT - ABSTRACT}

\section{Textile funcționalizate pe bază de psyllium și substanță proteică coloidală în combinație cu extract} de coada calului, pentru cosmetică

Scopul principal al acestei lucrări de cercetare a fost de a dezvolta produse cosmetice pentru îngrijire/vindecare, în care a fost selectată apa cu extract de coada calului, în calitate de compus de vindecare/îngrijire. Împreună cu aceasta, psyllium și cheratina (substanța proteică coloidală) au fost utilizate în calitate de compuși naturali capabili să formeze o structură de tip gel în mediile apoase, fiind explorate ca: i) purtători ai unui compus de îngrijire/vindecare (extract de coada calului) și ii) "liant”" (datorită viscozității relativ înalte) între compusul de vindecare și substratul textil (de exemplu, viscoza nețesută). Un astfel de sistem de funcționalizare a fost aplicat relativ ușor pe substratul de viscoză nețesut. Astfel, a fost creat produsul final, adică produsul cosmetic, care prezintă o bună activitate antioxidantă, stabilitate la depozitare și biodegradabilitate. Ultima proprietate este extrem de importantă pentru produsele ecologice.

Cuvinte-cheie: produse cosmetice, psyllium, coada calului, cheratină, vindecare/îngrijire

\section{Textile cosmetic pads based on psyllium and protein colloid in combination with the horsetail extract}

The basic purpose of this research work was to develop a care/healing cosmetic pads where a horsetail water extract was selected as a healing/care compound. Together with this, psyllium and keratin (protein colloid) were used as natural compounds capable to form a gel-like structure in aqueous media, so they were explored as i) carriers of a care/healing compound (horsetail extract), and as ii) "binding element" (due to relatively high viscosity) in-between the healing compound and the textile substrate (i.e. non-woven viscose) itself. Such functionalization system was relatively easily applied onto the non-woven viscose substrate. In this way the final product i.e. the cosmetic pad was created showing good ant oxidative activity, storage stability and biodegradability. The latest is extremely important for environmentally friendly products.

Keywords: viscose pads, psyllium, horsetail, keratin, healing/care

\section{INTRODUCTION}

Different natural and chemical compounds in the form of hydrogels, hydrocolloids, bio-films, foams, silicone, etc. are suitable as carriers of the healing substances [1-2]. Alternatively, such compounds can also be applied to any of the textile material, e.g. viscose, which is otherwise a leading substrate in the field of sanitation and medicine [1-2]. Satisfactorily antimicrobial [3], antioxidant, etc. action can be achieved with so called fiber functionalization. A modern concept of textile functionalization introduces natural compounds in the field of textile finishing due to the fact that they have no adverse impact on the potential user and the environment. Here, various plant extracts, or other natural active substances are of particular interest [1-2]. All these compounds must be skin-friendly in order to avoid possible side effects, water pollution, etc. [4]. Arising from these findings the aim of presented work was to create viscose nonwoven natural cosmetic/healing pads by using functionalization based on the horsetail extract as a main healing compound, individually, or in combination with psyllium and keratin. Both, psyllium and keratin colloids are very suitable for various uses, as they intensively swell in aqueous medium [5-11]. High swelling capacity rate possess also animal keratinbased adhesives [11-14]. These protein colloids (keratins) are interesting for water treatment applications [12], and also in the textile industry where are used as adhesives, especially in the field of leather industry, to replace conventional toxic substances [13]. Horsetail is rich source of silicon, and as such contributes to the form, resilience, and flexibility of all connective tissues [15]. All mentioned was the reason why it was used as the main part of the cosmetic pads in order to possibly reduce the skin redness, skin spots, or other skin inconvenience. In order to obtain hydrophilic colloidal systems, horsetail extract was combined with psyllium and keratin. To the best of our knowledge, in such form, this colloidal system was not used until now for viscose fiber functionalization. The obtained coating systems/adsorbates were analyzed from the viscosimetric point of view, supported with testing of their anti-microbial and antioxidant activity, biodegradability, followed by "in vivo" bioactive approach (preliminary visual testing). From practical point of view, ant oxidative properties are very important for medical textiles, since ant oxidative 
agents are known to cause reduced production of free radicals that increase oxidative stress, leading to DNA damage. Moreover, ant oxidative properties may also contribute to the anti-inflammatory effect [16].

\section{EXPERIMENTAL}

\section{Materials and procedures}

Dried horsetail plant, commercial psyllium, commercial keratin (rabbit skin glue binder), stabilizer sodium lactate $\left(\mathrm{C}_{3} \mathrm{H}_{5} \mathrm{O}_{3} \mathrm{Na}\right.$, Sigma Aldrich), non-woven viscose obtained by the process of carding, laying and needling, with a surface weight of $165 \mathrm{~g} / \mathrm{m}^{2}$, ready-touse in the form of a $45 \mathrm{~mm}$-width tape, on the back side combined with polypropylene (PP) (Producer Tosama d.o.o.) were used within experiment. Horsetail extract: The extract was prepared according to the following procedure: $20 \mathrm{~g}$ of dried horsetail plant was poured with $500 \mathrm{~mL}$ of demineralized water, then treated for $4 \mathrm{~h}$ at $100^{\circ} \mathrm{C}$, and finally left overnight to slowly cool down at the room temperature. Functionalization medium (coating systems): Psyllium in combination with demineralized water, and psyllium in combination with the horsetail extract were prepared in ratio of $200 \mathrm{~mL}$ of demineralized water: $3 \mathrm{~g}$ of psyllium, while keratin (rabbit skin glue binder) in combination with demineralized water, and keratin in combination with the horsetail extract in ratio of $200 \mathrm{~mL}$ of demineralized water: $20 \mathrm{~g}$ of rabbit skin glue binder. Viscose functionalization: Nonwoven viscose was functionalized according to the conventional impregnation method by using a tworoller foulard (W. Mathis); Conditions: 2 bar pressure, material transfer rate $2 \mathrm{~m} / \mathrm{min}$, and add-on 90-100\%. Before squeezing, the non-woven viscose was thoroughly soaked ( 1 hour) with all functionalization formulations as pointed out in the table 1.

\section{Methods}

Viscosimetry: The viscosity of prepared liquid functionalization formulations in $\mathrm{mPas}$ was determined by using viscometer FUNGILAB Smart Serial.

Antimicrobial activity: Antimicrobial testing was carried out in accordance with the standard AATCC 147 (test organism: S aureus, ATCC No 25923). Antioxidant activity: Antioxidant activity of functionalized non-woven viscose was evaluated by using the ABTS $^{*+}$ method (2,2'-azino-bis-3-ethylbenzothiazoline-6-sulfonic acid, Sigma Aldrich). The radical ABTS $^{*+}$ occurs during the oxidation of ABTS, and potassium persulfate absorbing in the visible region at a wavelength of $734 \mathrm{~nm}$. This is determined spectrophotometrically (eq. 1).

$$
\text { Inhibition }=(\text { Astarting }- \text { Asample }) / \text { Asample } \times 100 / \%
$$

where: Astarting is absorbance, measured at starting concentration of $\mathrm{ABTS}^{\bullet+}$, Asample - absorbance, measured at the rest concentration of ABTS ${ }^{\circ+}$ [16].

Determination of biodegradability: Textiles-determination of the resistance of cellulose-containing textiles to micro-organisms-Soil burial test - Part 1:
Assessment of rot-retardant Finishing (ISO 11721-1: 2001). In vivo preliminary testing: Preliminary in vivo testing was performed on population of four volunteers suffering from the skin problems.

\section{RESULTS AND DISCUSSION}

Viscosimetry: Results of the average viscosity (3 replicates) of the functionalization formulations used within research are collected in table 1.

Table 1

\begin{tabular}{|l|c|}
\hline \multicolumn{2}{|c|}{ FVISCOSITY IN mPas OF SEPARATE } \\
FUNCTIONALIZATION FORMULATION
\end{tabular}

Psyllium and protein colloid (rabbit skin glue binder) have high swelling ability in the aqueous medium so, they were selected to determine whether either of these compounds provides better properties in terms of stickiness and the ability to retain the horsetail extract in a gel-like structure. The interest was therefore, to achieve optimal viscosity in terms of the functionalization formulations practical use following optimal ratio between the solvent and the solute. On the basis of preliminary tests it was determined the optimal targeted viscosity which is in the case of psyllium of about $350 \mathrm{mPas}$, and in the case of a rabbit skin glue binder about $800 \mathrm{mPas}$. Based on this, the ratio between the solvent and the solute was defined: $200 \mathrm{~mL}$ of solvent: $3 \mathrm{~g}$ of psyllium i.e. ratio $67: 33$ ( $\mathrm{v}: \mathrm{m})$ and $200 \mathrm{~mL}$ of the solvent: $20 \mathrm{~g}$ of rabbit glue binder i.e. ratio 10:1 (v:m). Antimicrobial activity: The bacterial strain Staphylococcus aureus (Grampositive bacteria, ATCC No 25923) was used as the test organism. This type of micro-organism was selected on the basis of the assumption that it is a micro-organism that is present in most environments. An insufficient anti-microbial activity (AATCC standard 147) on Staphylococcus aureus is seen with all functionalized samples (no zone of inhibition). However, not only antimicrobial properties are essential for medical textiles development, but also antioxidant activity [18-19]. Functionalization of viscose with combination of psyllium and the horsetail extract proved to be more effective if compared to viscose, functionalized with combination of protein colloid (keratin) in combination with the horsetail extract. Anyway, it can be seen from results that functionalization where horsetail extract was used as a solvent for psyllium and the protein colloid (keratin), increased the antioxidant activity from $81 \%$ to $95 \%$ in the case of psyllium (if deionized water was used as a solvent) and in the case of a keratin from $55.9 \%$ 
to $71.5 \%$ (if deionized water was used as a solvent). Results show also good antioxidative activity of viscose, functionalized with psyllium in combination with deionized water $(81 \%)$, indicating that psyllium itself has good antimicrobial activity. Certain antioxidant activity (55.9\%) possesses also viscose, functionalized with keratin in combination with deionized water, which is related to the antioxidant activity of protein colloid (keratin) itself due to the presence of amino acid cysteine in its structure [20]. Antioxidant results are shown in figure 1.

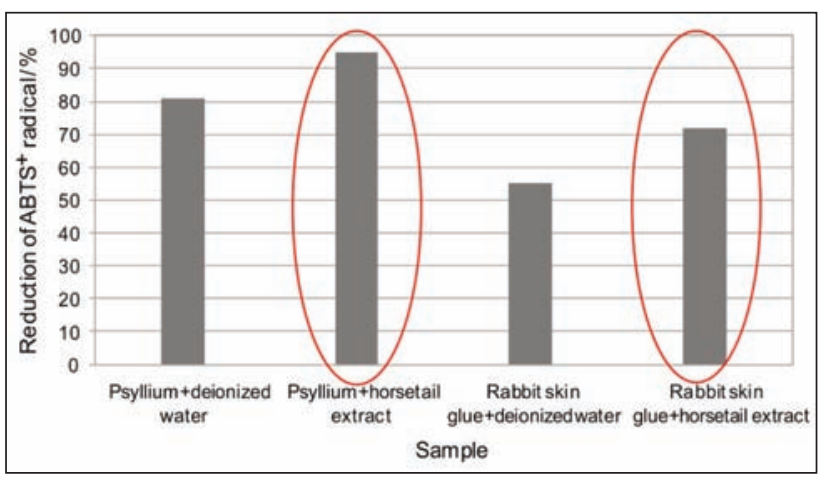

Fig. 1. Antioxidativity (reduction of radical $\mathrm{ABTS}^{\circ+}$ ) of functionalized non-woven viscose in dependence on functionalization formulation

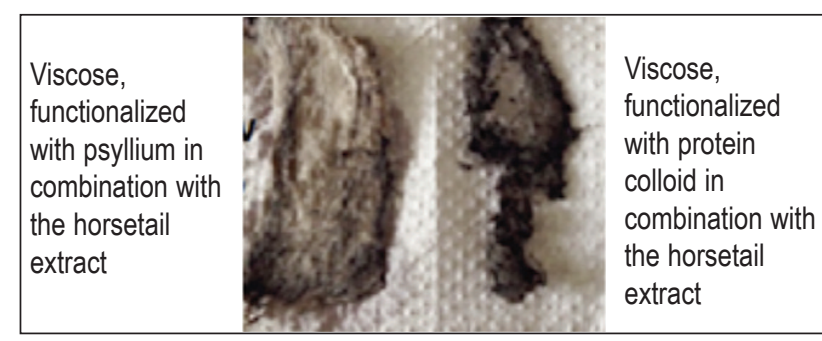

Fig. 2. Biodegradability of functionalized viscose samples after seven days of burial in the soil

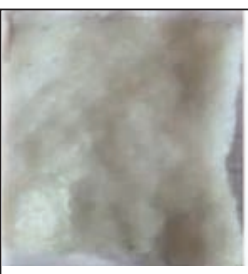

Reference, nonfunctionalized viscose

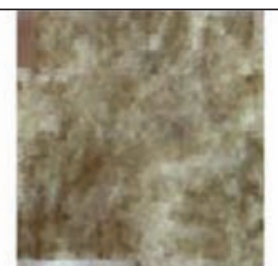

Viscose, functionalized with psyllium in combination with the horsetail extract

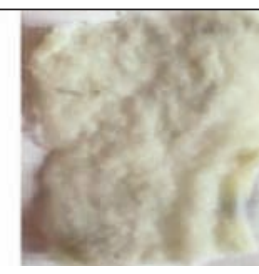

Viscose, functionalized with protein colloid in combination with the horsetail extract
Fig. 3. Biodegradability of functionalized viscose samples with added stabilizer after seven days of burial in the soil

Biodegradability and aging: Results show a significant degree of biodegradability of horsetail extract based functionalized samples after seven days of burial in the soil. In the case of viscose, functionalized with keratin in combination with horsetail extract, the appearance of biodegradability was even more pronounced than in the case of functionalization using psyllium in combination with the horsetail extract (figures 2-3).

After fourteen days, the cosmetic pads
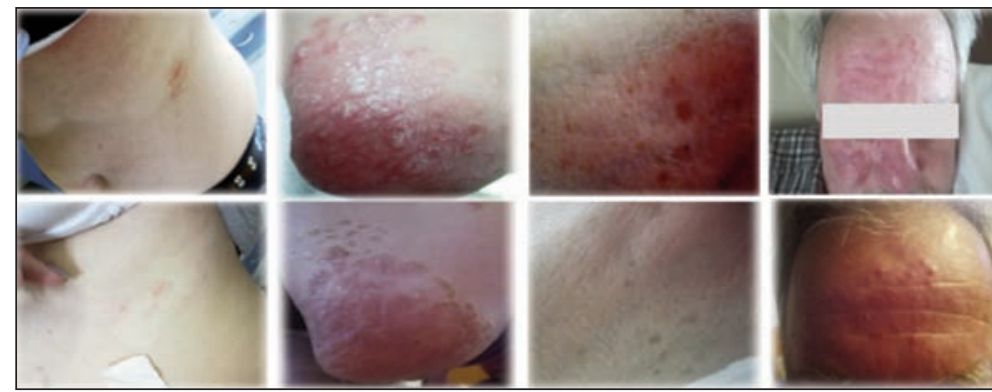
were completely decomposed. Thus, this product is also very friendly from environmentally point of view. In order to check the stability of prepared cosmetic pads under real storage conditions the cosmetic pads were packed in polyethylene (PE) bags and stored in a refrigerator which not proves to be effective, as after a few days a mould appeared and fully covered the surface of the pads. In this respect, appropriate solution based on the drying of the pads at room temperature was found as a good approach. These were subsequently rehydrated by the addition of about $5 \mathrm{ml}$ of distilled water, thereby establishing the original state of functionalized samples. In order to achieve certain stability of the functionalized samples even in wet conditions, $5 \%$ of natural stabilizer (Na lactate) was added to the separate functionalization formulation; the samples remained in perfect condition (visual estimation) after thirty days of storage in the refrigerator. Antioxidativity of samples remained almost the same.

Testing in vivo-preliminary study: The study included 4 test persons-volunteers who treated the various

Fig. 4. Results in-vivo-preliminary visual testing

parts of the body they considered as a skin problematic. In all cases, after one day of care, a significant improvement in the appearance of spots on certain parts of the body and the appearance of redness on the face and forehead was confirmed (figure 4 second line).

\section{CONCLUSIONS}

Psyllium and protein colloid (rabbit skin glue binder) were used as $i$ ) the carriers of the care/healing compound (horsetail extract) and as ii) the binding elements between the active substance (horsetail extract) and the textile (non-woven viscose). Great attention was paid to optimizing adequate viscosity for optimal coating of the samples. S. aureus is insufficiently reduced by all functionalized samples. On the other hand, high antioxidant activity of functionalized viscose samples with integrated horsetail extract is seen with all tested samples. Besides this, prepared pads are excellent biodegradable. The storage stability of textile pads in the refrigerator is prolonged 
when the stabilizer (Na-lactate) is part of the functionalization formulation. A great potential for the production of psyllium and protein colloid based textile pads with incorporated horsetail extract is confirmed with the research; preliminary in-vivo results showed extremely promising results.

\title{
BIBLIOGRAPHY
}

[1] Šauperl, O., Kralj Kunčič, M., Tompa, J., Fras Zemljič, L., Volmajer Valh J. Functionalization of non-woven viscose with formulation of chitosan and honey for medical applications, In: Fibres \& textiles in Eastern Europe, 2017, in progress.

[2] Šauperl, O., Tompa, J., Volmajer Valh, J. Influence of the temperature on the efficiency of cellulose treatment using copolymer chitosan-eugenol, In: Journal of engineered fibers and fabrics, 2014, vol. 9, no. 3, pp. 107-114.

[3] Fras Zemljič, L., Šauperl, O. Chitosan and its derivatives as an adsorbate for cellulose fibres' anti-microbial functionalizations, In: Industria textila, 2012, vol. 63, no. 6, pp. 296-301.

[4] Joshi, M., Ali, S.W., Purwar, R., Rajendran, S., Ecofriendly antimicrobial finishing of textiles using bioactive agents based on natural products, In: Indian Journal of Fibre \& Textile Research, 2009, vol. 34, pp. 295-304.

[5] Milton, H., Fiscera, A., Nanxiong Yu, B., et al. The gel-forming polysacharide of psyllium husk (Plantago ovata Forsk), In: Carbohydrate Research, 2014, vol. 339 (11), pp. 2009-2017.

[6] Banasaz, S., Hojatoleslami, M., Razavi, S., et al. The effect of psyllium seed gum as an edible coating and comparison to Chitozan on the textural properties and color changes of res delicious apple, In: International Journal of Farming and Allied Sciences, 2013, vol. 2 (18), pp. 651-657.

[7] Farahnaky, A., Askari, H., Majzoobi, M., Mesbahi, G.H. The impact of concentration temperature and $\mathrm{pH}$ on dynamic rheology of psyllium gels, In: Journal of Food Engineering, 2010, vol. 100 (2), pp. 294-301.

[8] Moreaux, S., Nichols, J., Bowman, J. GP., Hatfield, P.G. Psyllium lowers blood glucose and insulin concentration in horses, In: Journal of Equine Veterinary Science, 2011, vol. 31 (4), pp. 160-165.

[9] Anand, S., Kennedy, J., Miraftab, M., Rajendranet, S. Medical and healthcare textiles, In: Woodhead Publishing, 2010, vol. 560, pp. 249-250.

[10] Cavallaria, C., Brigidib, P., Finia, A. Ex-vivo and in-vitro assessment of mucoadhesive patches containing the gelformig polysacharide psyllium for buccal delivery of chlorhexidine base, In: International Journal of Pharmaceutics, 2015, vol. 496 (2), pp. 593-600.

[11] Singht, B. Psyllium as therapeutic and drug delivery agent, In: International Journal of Pharmaceutics, 2007, vol. $334(1-2)$, pp. 1-14.

[12] Wattie, B. Synthesis of keratin-based hydrogels and cryogels destined for environmental applications, In: Department of Bioresource Engineering, Faculty of Agricultural and Environmental Sciences, Macdonald Campus of McGill University Ste-Anne-de-Bellevue, Quebec, Canada, Bryan Wattie, 2016

[13] Sedliačik, J., Matyašovský, J., Smidriakov, M., Sedliacikova, M., Jurkovič, P. Application of collagen colloid from chrome sharings for innovative polycondensation adhesives, In: Journal of the American leather chemists association, 2011, vol. 106 (11), pp. 332-340.

[14] Manzano, E., Romero-Pastor, J., Navas, N., Rodríguez-Simón, L. R., Cardell, C. A study of the interaction between rabbit glue binder and blue copper pigment under UV radiation: A specroscopic and PCA approach, In: Vibrational Spectroscopy, 2010, vol. 53 (2), pp. 260-268.

[15] Nagai, T., Myoda, T., Nagashima, T. Antioxidative activities of water extract and ethanol extract from field horsetail (tsukushi) Equisetum L., In: Food chem., 2005, vol. 91, pp. 389-394.

[16] Fras Zemljič, L., Peršin, Z., Šauperl, O., Rudolf, A., Kostić, M. Medical textiles based on viscose rayon fabrics coated with chitosan encapsulated iodine: antibacterial and antioxidant properties, In: Textile research journal, First Published August 13, 2017, pp. 1-13.

[17] Ohba, R., Deguchi, T., Kishikawa, M., Arsyad, F., Morimura, S., Kida, K. Physiological functions of enzymatic hydrolysates of collagen or keratin contained in livestock and fish waste, In: Food Science and Technology Research, 2003, vol. 9 (1), pp. 91-93.

[18] Ristić, T., Hribernik, S., Fras Zemljič, L. Electrokinetic properties of fibres functionalised by chitosan and chitosan nanoparticles, In: Cellulose (2015), vol. 22 (6), pp. 3811-3823.

[19] Ristić, T., Zabret, A., Fras Zemljič, L., Peršin, Z. Chitosan nanoparticles as a potential drug delivery system attached to viscose cellulose fibers, In: Cellulose (2017), vol. 24 (2), pp. 739-753.

[20] Di Bernardini, R., Harnedy, P., Bolton, D., Kerry, J., O’Neill, E., Mullen, A.M., Hayes, M. Antioxidant and antimicrobial peptidic hydrolysates from muscle protein sources and by-products, In: Food Chemistry, 2011, vol. 124 (4), pp. 1296-1307.

\section{Authors:}

\author{
OLIVERA ŠAUPERL, LIDIJA FRAS ZEMLJIČ, JULIJA VOLMAJER VALH, JASNA TOMPA \\ University of Maribor, Faculty of Mechanical Engineering, \\ Smetanova ulica 15, SI-2000, Maribor, Slovenia \\ e-mail: olivera.sauperl@um.si, lidija.fras@um.si, julija.volmajer@um.si, jasna.tompa@um.si
}

\section{Corresponding authors:}

OLIVERA ŠAUPERL

e-mail: olivera.sauperl@um.si 